\title{
Meningioma: The Unusual Growth in a Transsexual Patient after Estrogen-Progesterone Therapy
}

\author{
Hamid Borghei-Razavi ${ }^{1 *}$, Valente Fragoza-Padilla ${ }^{1}$, Gunnar Hargus ${ }^{2}$, Sahar Bakhti ${ }^{3}$ \\ and Uta Schick ${ }^{1}$ \\ ${ }^{1}$ Department of Neurosurgery, Clemens Hospital, Münster, Germany \\ ${ }^{2}$ Institute of Neuropathology, Münster University, Münster, Germany \\ ${ }^{3}$ Department of Neurosurgery, Iran University of Medical Science, Tehran, Iran
}

\begin{abstract}
Received: August 11, 2014; Accepted: August 28, 2014; Published: September 10, 2014
*Corresponding author: Hamid Borghei-Razavi, Department of Neurosurgery, Clemens Hospital, Academic Hospital of Münster University, Duesbergweg 124, 48153 Münster, Germany, Tel: 0049-251-9760; E-mail: h.borghei-razavi@clemenshospital.de
\end{abstract}

Keywords: Meningioma; Progesterone receptors; Estrogen receptors hormone therapy; Tempolopolar region; Medial pre-optic nucleus; Ventromedial nucleus; Cross-sex hormone treatment; Tumor incidence; Hormone replacement therapy; Semi-progesterone effects; Cyproteron acetate; Progynova; Transsexual patient

\section{Introduction}

The frequency of meningioma is nearly twice as high in females as in males [1]. This difference in incidence is partly explained by molecular and immunehistochemical studies' indicating that meningioma is sensitive to hormones. Approximately $70 \%$ of meningiomas express progesterone receptors and $30 \%$ express estrogen receptors [2-4]. It has also been observed that meningioma cells tend to proliferate when exposed to estrogen and progesterone [4].

Although cross-sex hormone treatment is an important component of medical treatment of transsexual patients, several adverse effects are associated with its use, such as osteoporosis, cardiovascular disease, hormone-dependent tumors (e.g., lactotroph adenomas), breast and prostate carcinomas. Specifically, research on Hormone Replacement Therapy (HRT) indicates that the risk of developing meningioma may be higher in transsexual patients due to relatively high doses of sex hormones $[5,6]$

In this article, we report a case of meningioma in a male-tofemale transsexual patient undergoing HRT and propose that exposure to estradiol may have promoted fast meningioma tumor cell growth in an unusual manner. Thus, we hypothesize that the risk of developing a hormone-dependent tumor such as meningioma should be taken into account when evaluating potential candidates and examining patients undergoing maleto-female HRT.

\section{Case Report}

A 56-year-old male-to-female transsexual patient reported progressive severe left parietal headache during the previous
1.5 years. The neurological exam detected no abnormalities, but a review of clinical history revealed that the patient had been treated with Progynova (containing $2 \mathrm{~g}$ estradiol) for 8 years as well as cyproterone acetate, an anti-androgenic drug with semiprogesterone effects.

An initial Magnetic Resonance Imaging (MRI) exam in April 2011 showed positive evidence of a temporopolar meningioma (Figure 1). Consequently, the physician ordered the withdrawal of all hormonal medication. However, the patient, out of concern about losing female phenotype, continued to take Progynova.

A follow-up MRI occurring 6 months later showed that the temporal mass had unexpectedly increased in volume (Figure 2, Table 1). Therefore, the tumor was completely respected without any complication. Histopathology showed a transitional meningioma (WHO grade I) that was progesterone receptorpositive and estrogen receptor-negative (Figure 3).

\section{Discussion}

Cross-sex hormonal therapy is a fundamental component of

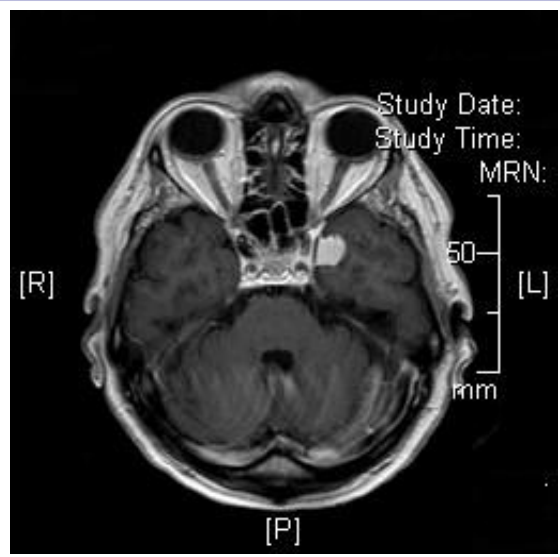

Figure 1: Initial MRI on April 2011 showing left Temporopolar Meningioma. 
the endocrine regimen recommended for transsexual patients, but several studies associate HRT with a higher risk of developing intracranial meningioma (Table 2) [7-9]. Indeed, current endocrinological practice, the presence of pituitary adenomas contraindicates HRT and indicates that prolactin levels should be routinely monitored in male-to-female transsexuals $[8,10]$.

More detailed molecular and immunohistochemical research provides evidence that meningiomas are hormone-sensitive tumors, with $70 \%$ of cells expressing progesterone receptors and around 30\% expressing estrogen receptors [2-4]. Many of these studies also report that human meningioma cells proliferate when exposed to progesterone and estrogen [4]. Most meningiomas express functional progesterone rather than estrogen receptors $[1,11]$ and show growth during the progesterone-predominant luteal phase [12].

Other studies have investigated the effects of estradiol treatment on progesterone receptors. Estradiol up-regulates progesterone receptors through $\alpha$-estradiol receptors and can also stimulate hypothalamic progesterone receptors in the Medial Pre optic Nucleus (MPN) [13]. Some studies show that estradiol plays an important role in the ontogenic expression of progesterone receptors during postnatal uterine maturation in rats [14]. However, another study investigated the functionality of progesterone or estradiol receptors using polymerase chain reaction and provided evidence of a non-functional progesterone receptor in vitro [15].

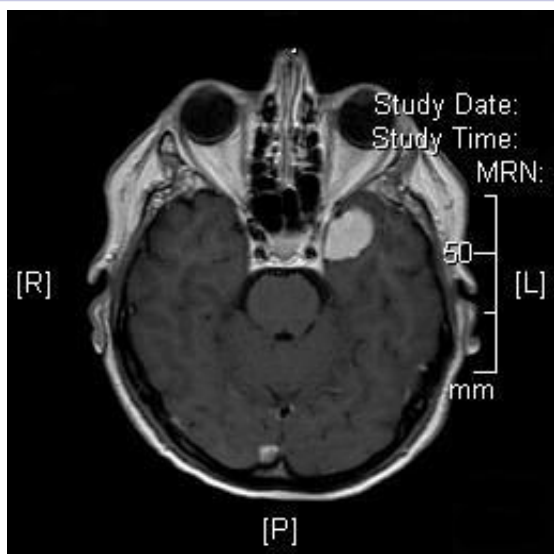

Figure 2: Six months later another MRI showing that the temporal mass had unexpectedly increased in volume.

Table 1: The rate of tumor growth 6 month after first MRI examination considering the natural history of meningioma.

\begin{tabular}{|c|c|}
\hline $\begin{array}{c}\text { Tumor Growth in first } \\
\text { Examination }\end{array}$ & $\begin{array}{c}\text { Tumor growth in second } \\
\text { examination after } \mathbf{6} \text { months }\end{array}$ \\
\hline $12 \times 21 \times 11 \mathrm{~mm}^{\S}$ & $22 \times 26 \times 20 \mathrm{~mm}$ \\
\hline \multicolumn{2}{|c|}{ The tumor growth in our patient: } \\
$10 \times 5 \times 9 \mathrm{~mm} / 6$ month
\end{tabular}

The average of tumor growth in patients without any hormonal usage: $4 \mathrm{~mm} /$ year (18)

§Tumor growth defined as a the greatest distance of tumor border from dura in coronal, axial and sagital plane
Table 2: The summary of three cases of unusual meningioma's growth in transsexual patients after Estrogen-Progesterone Therapy (MTF: Male to Female, PR: Progesterone receptor, ER: Estrogen Receptor).

\begin{tabular}{|c|c|c|}
\hline Case Report & Medication & Considerations \\
\hline $\begin{array}{c}\text { Gazzeri et al, 2007 [8] } \\
\text { NEJM }\end{array}$ & $\begin{array}{c}\text { Ethinyl Estradiol } \\
(100 \text { microgram/day }) \\
\text { \& Cyproterne acetate } \\
(100 \mathrm{mg} / \mathrm{d})\end{array}$ & $\begin{array}{c}\text { Frontobasal } \\
\text { Meningioma } \\
\text { ER - }\end{array}$ \\
$\begin{array}{c}\text { Ki-67 index of 5\% } \\
\text { MIB-1 index of 3.4\% }\end{array}$ \\
\hline $\begin{array}{c}\text { Deipolyi et al, 2010 [7] } \\
\text { Neurnal of clinical }\end{array}$ & $\begin{array}{c}\text { Estradiol 0.1 mg } \\
\text { biweekly patches for } \\
\text { more than 10 years }\end{array}$ & $\begin{array}{c}\text { Left Occipital mass } \\
\text { PR + }\end{array}$ \\
\hline $\begin{array}{c}\text { Cebula et al, 2010 [9] } \\
\text { Acta Neurochirurgie }\end{array}$ & $\begin{array}{c}\text { Discontinuation of } \\
\text { Cyproterone acetate }\end{array}$ & $\begin{array}{c}\text { Regression of the left } \\
\text { temporal meningioma } \\
\text { after discontinuation } \\
\text { of Cyproterone acetate }\end{array}$ \\
\hline
\end{tabular}
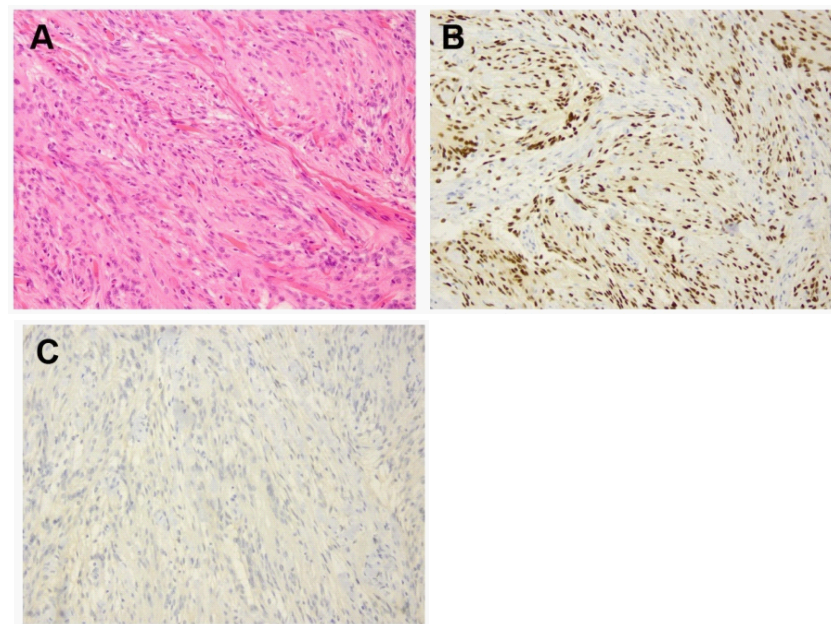

Figure 3: (A) Haematoxylin/eosin staining of the meningeoma. (B) Strong expression of progesterone receptor in the nucleus of tumour cells. (C) Lack of estrogens receptor expression in tumour cells.

In experiments performed in rats during their growth phase, males expressed high levels of progesterone receptors in the MPN, whereas females had virtually no progesterone receptors, suggesting that exposure to estradiol has sex-dependent effects. The same study also found that the expression of progesterone receptors in the adult ventromedial nucleus depends on estradiol. Therefore, regulation of progesterone receptor expression through estradiol depends on age, sex, and brain region [16].

Most studies suggest that progesterone may contribute to meningioma pathogenesis, and trials of anti-progesterone treatment for inoperable meningiomas have shown excellent results. As a result, anti-progesterone drugs and the discontinuation of synthetic progesterone have been shown to inhibit meningioma cell growth, and the discontinuation of cyproterone acetate induces an abrupt regression of the tumor [17]. Accordingly, anti-progesterone therapy (e.g., Mifepristone, RU486) shows promise as a hormonal treatment for sphenoid ridge meningioma [18]. 
Table 3: The mechanism of medical effect on meningioma growth in our patient.

\begin{tabular}{|c|c|c|}
\hline Medication & Mechanism 1 & Mechanism 2 \\
\hline Progynova & $\begin{array}{c}\text { Estrogen effect } \\
\text { (Estradiol valerate) }\end{array}$ & ---------------- \\
\hline Ciproterone Acetat & Antiandrogenic effect & $\begin{array}{c}\text { Semi progesterone } \\
\text { effect }\end{array}$ \\
\hline
\end{tabular}

Despite the presence of progesterone-positive receptors and a low grade tumor in our patient, we consider that the contraindicated use of estradiol by the patient may have contributed to the unusually fast tumor growth. The tumor in our patient was progesterone receptor-positive and estrogen receptor-negative (Figure 3). However, the patient had been treated with Progynova containing $2 \mathrm{~g}$ estradiol and Cyproteron acetate, which is an anti-androgenic drug and has semiprogesterone effects (Table 3). In reviewing the literature, we found studies that examined the effects of estradiol on progesterone receptors experimentally. This literature indicates that estradiol up-regulates estrogen and progesterone receptors [13] and can induce expression of hypothalamic progesterone receptors [19]. As a result, we believe that the indirect effect of estrogen on progesterone receptors (i.e., up-regulation of progesterone receptors in the tumor and hypothalamus) changed the natural history of the meningioma and enhanced tumor growth in our patient.

The average annual growth rate for most meningiomas is about $4 \mathrm{~mm}$ per year [20]. In our case, the tumor grew $10 \mathrm{~mm}$ in 6 months (Table 1). Thus, despite immunohistochemical evidence that the meningioma was progesterone receptor-positive and estrogen receptor-negative, we propose that estradiol may have an effect on meningioma growth (Table 3).

Given that the prevalence of meningioma in U.S. men is $5: 100,000$ and the prevalence of male-to-female transsexuals is almost $1: 10,000$, the probability of an incidental meningioma in male-to-female transsexuals is about 1:200,000,000. This suggests that such an occurrence may not be coincidental [7]. Hence, in male-to-female transsexual patients undergoing HRT who are found to have a meningioma, the cessation of all sex hormones, not only progestin's, is advised.

\section{References}

1. Claus EB, Bond ML, Schildkraut JM, Wiemels JL, Wrensch M, Black PM. Epidemiology of intracranial meningioma. Neurosurgery. 2005; 57(3):1088-1095: 1088-1095.

2. Blitshteyn S, Crook JE, Jaeckle KA. Is there an association between meningioma and hormone replacement therapy? J Clin Oncol. 2008; 26(2):279-82. doi:10.1200/JC0.2007.14.2133.

3. Hsu DW, Efird JT, Hedley-Whyte ET. Progesterone and estrogen receptors in meningiomas: prognostic considerations. J Neurosurg. 1997; 86(1):113-20. doi:10.3171/jns.1997.86.1.0113

4. Speirs V, Boyle-Walsh E, Fraser WD. Constitutive co-expression of estrogen and progesterone receptor mRNA in human meningiomas by RT-PCR and response of in vitro cell cultures to steroid hormones. Int J Cancer. 1997; 72(5):714-9.
5. Gooren LJ, Giltay EJ, Bunck MC. Long-termtreatment of transsexuals with cross-sex hormones: extensive personal experience. J Clin Endocrinol Metab. 2008;93(1):19-25. doi:10.1210/jc.2007-1809

6. Moore E, Wisniewski A, Dobs A. Endocrine treatment of transsexual people: a review of treatment regimens, outcomes, and adverse effects. J Clin Endocrinol Metab. 2003; 88(8):3467-73. doi:10.1210/ jc.2002-021967

7. Deipolyi AR, Han SJ, Parsa AT. Development of a symptomatic intracranial meningioma in a male-to-female transsexual after initiation of hormone therapy. J Clinical Neuroscience. 2010; 17(10):1324-6. doi: 10.1016/j.jocn.2010.01.036

8. Gazzeri R, Galarza M, Gazzeri G. Growth of a meningioma in a transsexual patient after estrogen-progestin therapy. N Engl J Med. 2007;357(23):2411-2. doi:10.1056/NEJMc071938

9. Cebula H, Pham TQ, Boyer P, Froelich S. Regression of meningiomas after discontinuation of cyproterone acetate in a transsexual patient. Acta Neurochir (Wien). 2010; 152(11): 1955-6. doi: 10.1007/s00701010-0787-2.

10. Lieu AS, Hwang SL, Howng SL. Intracranial meningioma and breastcancer. J Clin Neurosci. 2003;10(5):553-6.

11. Wahab M, Al-Azzawi F. Meningioma and hormonal influences. Climacteric. 2003;6(4):285-92.

12. Olson JJ, Beck DW, Schlechte J, Loh PM. Hormonal manipulation of meningiomas in vitro. J Neurosurg. 1986; 65(1):99-107. doi:10.3171/ jns.1986.65.1.0099

13. Romeo RD, Wagner CK, Jansen HT, Diedric SL, Sisk CL. Estradiol induces hypothalamic progesterone receptors but does not activate mating behaviour in male hamsters (Mesocricetus auratus) beforepuberty. Behavioral Neurosci. 2002;116(2):198-205.

14. Ohta Y, Fukazawa Y, Sato T, Tomomi Sato, Atsushi Suzuki, Naomi Nishimura, and Taisen Iguchi. Effect of estrogenon ontogenic expression of progesterone and estrogen receptors in rat uterus. Zoological Sci 1996;13(1):143-9. doi:http://dx.doi.org/10.2108/ zsj.13.143

15. Adams EF, Schrell UM, Fahlbusch R, Thierauf P. Hormonal dependency of cerebral meningiomas. Part 2: In vitro effect of steroids, bromocriptine, and epidermalgrowth factor ongrowth of meningiomas. J Neurosurg 1990;73(5):750-5. doi:10.3171/ jns.1990.73.5.0750

16. Quadros PS, Wagner CK. Regulation of progesterone receptor expressionby estradiol is dependent on age, sex and region in the rat brain. Endocrinology 2008;149(6):3054-61. doi:10.1210/en.20071133

17. Gonçalves AM, Page P, Domigo V, Meder JF, Oppenheim C. Abrupt regression of a meningioma after discontinuation of cyproterone treatment. AJNR Am J Neuroradiol. 2010; 31(8):1504-5. doi:10.3174/ ajnr.A1978

18. De Keizer RJW, Smit JWA. Mifepristone treatment in patients with surgically incurable sphenoid-ridge meningioma: a long-term followup. EyeLondEngl. 2004;18(9):954-8. doi:10.1038/sj.eye.6701370

19. Nguyen BL, Hatier R, Jeanvoine G, Roux M, Grignon G, Pasqualini JR. Effect of estradiol on the progesterone receptor and on morphological ultra structures in the fetal and new born uterus and ovary of the rat. Acta Endocrinol. 1988; 117(2): 249-259

20. Rubin G, Herscovici Z, Laviv Y, Jackson S, Rappaport ZH. Outcome of untreated meningiomas. Isr Med Assoc J IMAJ. 2011;13(3):157-60. 